Jurnal MAKSIPRENEUR, Vol. II, No. 2, Juni 2013, hal. 80 - 100

\title{
ANALISIS PENGARUH ATRIBUT IKLAN TELEVISI TERHADAP EKUITAS MEREK
}

\author{
Muhamad Ali Sukrajap, S.E., M.B.A (dhou.personal@gmail.com)
}

\begin{abstract}
ABSTRACK. The corporate world has level changes very quickly. It is no wonder that the producers are vying to sell their products in order to quickly sell at the market. Frequently used media channels are through advertising. One of the kind advertising are television commercials. The making of television advertising must be pleasing consumers, meaning that in designing the ads need to pay attention to the ad attribute in order to make consumers interested in finding out more about the product and brand preference of the planting efforts in the minds consumers. Television advertising is one way to manage a good brand equity. This study aims to measure the extent of the influence of television advertising in the attribute of ad Sprite version "Speed" affecting equity product brand of Sprite. The data used in this research in the form of primary data taken directly from the data source through the survey with the total number of respondents (n) of 100 respondents. All data processed by using Structural Equation Model analysis tools in LISREL 8.54. From the results of the study, the researchers concluded that, in general there are positive influence of the television commercials attributes against the brand equity of the product but if we break into one on one relationship there are some specifically outlined the ads have no effect positively towards brand equity i.e. the animation and color while the ad attributes the most positive influence is the tagline.
\end{abstract}

Keyword: Periklanan, Atribut Iklan Televisi dan Ekuitas Merek.

\section{PENDAHULUAN}

Dunia usaha memiliki tingkat perubahan sangat cepat. Perubahan iklim usaha susah ditebak dan bersifat statis mengharuskan setiap perusahaan senantiasa melakukan upaya perbaikan produk. Perbaikan produk tidak hanya meliputi mutu kualitas produk perusahaan juga proses produk sampai pada pengguna akhir atau dengan kata lain dapat terjual. Komunikasi pemasaran merupakan upaya menjembatani antara produsen yang mengenalkan produknya dengan konsumen yang menginginkan produk tersebut. Terdapat berbagai macam bentuk promosi seperti periklanan, penjualan langsung, promosi penjualan, publisitas, dan penjualan personal. Salah satu bentuk komunikasi pemasaran yang berkembang cepat yaitu periklanan. Periklanan adalah bentuk komunikasi tidak langsung dari yang didasari pada informasi tentang keunggulan atau keuntungan suatu produk yang disusun sedemikian rupa sehingga menimbulkan rasa menyenangkan yang akan mengubah pikiran seseorang untuk melakukan pembelian.

Iklan merupakan salah satu alat promosi yang paling banyak digunakan perusahaan untuk menginformasikan, membujuk, dan mengingatkan pembeli sasaran atau masyarakat mengenai keberadaan suatu produk atau jasa yang pada akhirnya dimaksudkan untuk meningkatkan penjualan (Shultz, 1990 dalam Purnama, 2003, hal. 1). Alat promosi yang digunakan tergantung pada kebutuhan produsen. Rhenald Kasali (1992, hlm. 9) berpendapat bahwa iklan merupakan segala bentuk pesan tentang suatu produk yang disampaikan lewat media, ditujukan kepada sebagian atau seluruh masyarakat. Salah 
satunya saluran media iklan yang banyak mendapat perhatian konsumen akhir-akhir ini yaitu televisi. Televisi adalah salah satu bentuk multimedia yang mampu menyajikan bentuk komunikasi audio-visual. Pembuataan iklan harus dibuat semenarik mungkin. Iklan memiliki daya tarik tersendiri. Daya tarik iklan (advertising appeal) harus memiliki 3 sifat yaitu: iklan yang bermakna (meaningful) artinya menunjukkan manfaat-manfaat yang membuat produk tersebut lebih diinginkan atau lebih menarik bagi konsumen, iklan yang dapat dipercaya (believeble) artinya konsumen harus percaya bahwa produk atau jasa tersebut akan memberikan manfaat seperti yang dijanjikan. Iklan yang memiliki ciri khas (distinctive), artinya iklan tersebut harus menceritakan bahwa produk tersebut lebih baik dibanding merek-merek pesaing. (Kotler dan Amstrong, 2004, hal. 646). Iklan di televisi mempunyai durasi yang sangat singkat disebabkan oleh biaya iklan yang sangat mahal sehingga iklan tersebut tidak mampu untuk menjelaskan secara keseluruhan dan details informasi mengenai produk. Pembuataan iklan televisi haruslah menyenangkan konsumen. Artinya mendesain iklan yang membuat konsumen tertarik untuk mengetahui lebih lanjut mengenai produk serta upaya penanaman preferensi merek dalam benak konsumen.

Merek dianggap lebih lazim dan lebih banyak menjadi obyek loyal karena dianggap sebagai identitas produk atau perusahaan yang lebih mudah dikenali oleh pelanggan (Dharmasesta, 1999). David A. Aekar (1996) menyatakan bahwa merek memberikan "nilai" sehingga nilai total produk yang "bermerek" baik menjadi lebih tinggi dibandingkan produk yang dinilai semata-mata secara obyektif. Salah satu pertimbangan yang dapat dikemukakan adalah reputasi tinggi merek yang baik tentunya tidak jatuh dari langit tetapi dibangun melalui proses yang bahkan tidak jarang memakan waktu ratusan tahun. David A. Aekar (1996) menyebut nilai tersebut ekuitas merek (brand equity), yang elemen-elmennya meliputi: brand awareness, brand association, perceived quality, dan brand loyalty. Mengingat bahwa iklan sebagai salah satu penguat dari preferensi merek produk, maka atribut iklan memiliki pengaruh terhadap citra merek produk pada iklan televisi. Terdapat banyak sekali iklan di televisi yang terus ditayangkan dengan frekuensi dan jam tayang berbeda-beda. Perbedaan itu pula mempengaruhi atribut iklan televisi yang harus disusun. Dalam iklan televisi memang terdapat keberagaman pada sisi penyajian. Penyajian iklan menyesuiakan dengan karateristik konsumen, saluran media dan jenis produk agar lebih menarik. Keberadaan atribut tersebut mempengaruhi kualitas iklan. Bila mengamati iklan televisi lebih jauh terdapat beberapa atribut iklan televisi yang biasa digunakan oleh agen periklanan dalam merancang iklan televisi. Dimana pemirsa diajak untuk memahami iklan melalui kisah cerita, membuat slogan atau tagline tepat untuk menggambarkan karateristik produk, menambah kesan menarik lewat animasi, menstimuli memori melalui musik dan warna serta penggunaan endoser untuk menarik perhatian konsumen. Adapun atribut iklan tersebut adalah kisah cerita, tagline, animasi, musik, endoser, dan warna

Salah satu iklan yang sering kita lihat ditelevisi adalah Sprite, dengan tagline "Bebaskan Gerah Sensasi Plong”. Sprite merupakan produk dengan kategori minuman siap minum (ready to drink) yang dikeluarkan oleh Coca Cola Indonesia. Pertama kali diperkenalkan di tahun 1960, Sprite adalah minuman ringan dengan aroma rasa lemon yang paling digemari. Hal ini disebabkan segmen pasar yang dibidik adalah anak muda dimana ditandai oleh sebagian besar model iklannya adalah anak muda. Untuk mengkomunikasikan produk Sprite ini maka Marketing PT Coca Cola Indonesia membuat iklan yang sesuai dengan segmentasi geografis di indonesia. Iklan yang diangkat pada penelitian ini yaitu iklan Sprite versi Speed. Penggambaran iklan ini dimulai saat beberapa pemuda yang sedang kehausan di bawah terik matahari pada siang 
hari kemudian menjadi segar dan bersemangat untuk mengejar bus yang terlewat saat menunggunya di halte bus. Gabungan atribut iklan mulai dari naskah berupa kisah cerita sangatlah menarik yang dipadupadankan dengan animasi memberi nyawa pada iklan. Warna dominan hijau yang melambangkan kesegaran yang dimunculkan mempertegas tagline produk ini "Bebaskan Gerah Sensasi Plong" yang diperkuat dengan endoser berupa pemuda. Hal tersebut bertambah lengkap saat musik mengiringinya adegan kejar bus mengantarkan kita sebagai konsumen untuk ikut merasakan semangat yang timbul saat setelah minum produk ini. Korelasi diantara atribut iklan sangat penting dalam efektifitas iklan sebab akan mempengaruhi penerimaan iklan oleh konsumen dengan baik. Saat bersamaan maka ekuitas merek secara tidak langsung terbentuk dalam benak konsumen. Dalam penelitian ini yang menjadi rumusan masalah adalah: a. Apakah atribut iklan seperti kisah cerita, tagline, animasi, musik, endoser dan warna berpengaruh positif terhadap ekuitas merek ?, b. Atribut iklan apakah yang paling positif pengaruhnya terhadap ekuitas merek?

\section{HASIL PENELITIAN TERDAHULU}

Ada beberapa penelitian yang mengkaji tentang iklan dan merek diantara yang dilakukan oleh Nispan Arry Yulianto, UII (2006) yang meneliti pengaruh ekuitas merek terhadap keputusan pembelian dengan subyek penelitian yaitu Handphone Nokia. Penulis ingin mengetahui apakah variabel-variabel ekuitas merek (brand awareness, brand association, perceived quality, dan brand loyalty) mempengaruhi keputusan pembelian konsumen terhadap handphone merek Nokia baik secara parsial maupun bersama-sama, serta variabel manakah yang paling mempengaruhi keputusan pembelian konsumen terhadap handphone merek Nokia. Dengan teknik pengumpulan data menggunakan kuesioner dan menganalisis data dengan menggunakan metode regresi linier berganda, korelasi berganda dan korelasi parsial, diperoleh hasil bahwa variabel-variabel ekuitas merek (brand awareness, brand association, perceived quality, dan brand loyalty) secara individu dan bersama-sama mempunyai pengaruh yang signifikan terhadap keputusan pembelian handphone merek Nokia. Kesimpulan yang kedua variabel kesadaran merek (brand awareness) merupakan variabel yang paling mempengaruhi keputusan pembelian konsumen terhadap handphone merek Nokia. Variabel ekuitas merek yang terdiri dari brand awareness, brand association, perceived quality, dan brand loyalty mempunyai pengaruh yang signifikan terhadap keputusan pembelian handphone Nokia. Hal ini dapat kita lihat pada hasil analisis regresi berganda, nilai koefisien regresi untuk variabel kesadaran merek (brand awareness) merupakan faktor yang paling mempengaruhi keputusan pembelian konsumen terhadap handphone Nokia. Hal ini dibuktikan dengan nilai koefisien korelasi parsial variabel brand awareness yang paling besar yaitu sebesar 0,336 atau $33,6 \%$.

Berikutnya Sri Yeni Maesaroh, MM UII (2006) dalam tesisnya berjudul Hubungan Kekuatan Iklan Frestea Green di Televisi Terhadap Respon Konsumen di Yogyakarta Berdasarkan Model Hierarki Efek, menjelaskan besarnya pengaruh iklan televisi terhadap respon konsumen terutama mahasiswa. Menurutnya bahwa terdapat hubungan antara daya tarik iklan, lama penayangan, frekuensi penayangan dan media penayangan secara bersama-sama dengan respon konsumen berdasarkan tahapan model hirarki efek yaitu kesadaran (awareness), pengetahuan (knowledge), suka (lingking), menjadikan produk sebagai pilihan (preference), keyakinan (conviction), dan pembelian (purchase). Diantara variabel-variabel daya tarik iklan, lama penayangan, frekuensi penayangan dan media penayangan, yang paling berhubungan erat atau signifikan dengan respon konsumen berdasarkan tahapan model hirarki efek yaitu kesadaran (awareness), pengetahuan 
(knowledge), suka (lingking), menjadikan produk sebagai pilihan (preference), keyakinan (conviction), dan pembelian (purchase) adalah daya tarik iklan.

\section{LANDASAN TEORI}

\section{a. Konsep Merek}

Menurut American Marketing Association, Merek adalah nama, istilah, tanda, simbol, atau rancangan atau kombinasi dari hal-hal tersebut. Tujuan pemberian merek adalah untuk mengidentifikasikan produk atau jasa yang dihasilkan sehingga berbeda dari produk atau jasa yang dihasilkan oleh pesaing" (Rangkuti, 2002, hal. 1). Merek dapat juga dibagi dalam pengertian lainnya seperti: Brand name (nama merek), Brand mark (tanda merek), Trade mark (tanda merek dagang), dan Copyright (hak cipta).

\section{b. Ekuitas Merek}

Merek memberikan "nilai" sehingga total produk yang "bermerek" baik menjadi lebih tinggi dibandingkan produk yang dinilai semata-mata secara objektif. David A. Aekar (1997, dalam Durianto, Sugiarto, dan Budiman, 2004, hal. 1) menyebutnya nilai tersebut ekuitas merek (brand equity). Ekuitas merek adalah nilai tambah yang diberikan merek kepada produk. Ekuitas itu dianggap ada jika merek itu memberikan nilai tambah, jika tidak memberikan nilai tambah apalagi jika dapat mengurangi nilai produk berarti tidak ada ekuitas merek (Hana dan Wozniak dalam Bilson Simamora, 2002, hal. 49). Ekuitas merek dapat dibagi menjadi 4 kategori: (David A. Aekar, 1997, hal. 23)

1. Kesadaran Merek (brand awareness)

Kesadaran (awareness) menggambarkan keberadaan merek didalam pikiran konsumen, yang dapat menjadi penentu dalam beberapa kategori dan biasanya mempunyai peranan kunci dalam brand equity. Kesadaran merek adalah kesanggupan seseorang calon pembeli untuk mengenali atau mengingat kembali bahwa suatu merek merupakan bagian dari kategori tertentu (David A. Aekar, 1997, hal. 90).

2. Asosiasi Merek (brand assosiation)

Menurut David A. Aekar (1997, hal. 160), asosiasi merek adalah segala hal yang berkaitan dengan ingatan mengenai merek. Keterkaitan pada suatu merek akan lebih kuat apabila dilandasi pada banyak pengalaman atau penampakan untuk mengkomunikasikannya. Berbagai asosiasi yang diingat konsumen dapat dirangkai sehingga membentuk citra tentang merek atau brand image di dalam benak konsumen. Brand image itu sendiri berarti sekumpulan asosiasi merek yang terbentuk di benak konsumen.

3. Kesan Kualitas (perceived quality)

Kesan kualitas bisa didefinisikan sebagai persepsi pelanggan terhadap keseluruhan kualitas atau keunggulan suatu produk atau jasa layanan berkaitan dengan maksud yang diharapkan (David A. Aekar, 1997, hal. 124). Terdapat faktor yang mempengaruhi kesan kualitas terhadap merek. Faktor tersebut tercermin dalam dimensi kesan kualitas sebuah produk. Menurut David A. Aekar (1997, hal. 134-136), dimensi kesan kualitas dibagi menjadi tujuh, yaitu Kinerja, Pelayanan, Ketahanan, Keandalan, Karakteristik produk, Kesesuaian dengan spesifikasi dan Hasil.

4. Loyalitas Merek (brand loyalty)

Kepuasan adalah pengukuran secara langsung bagaimana konsumen tetap loyal pada suatu merek. Kepuasan terutama menjadi pengukuran di bisnis jasa. Sementara itu loyalitas merupakan hasil akumulasi pengalaman penggunaan produk (Durianto, Sugiarto, dan Budiman, 2004, hal. 19). Loyalitas merek adalah ukuran dari kesetiaan 
konsumen terhadap suatu merek. Terdapat lima tingkatan loyalitas merek (Aaker, 1976, hal. 57):

a. Tingkat loyalitas yang paling dasar adalah pembeli tidak loyal/sama sekali tidak tertarik pada merek-merek apapun yang ditawarkan..

b. Tingkat kedua adalah pembeli merasa puas dengan produk yang ia gunakan, atau minimal konsumen tidak kecewa dengan produk tersebut.

c. Tingkat ketiga adalah orang-orang/konsumen-konsumen yang merasa puas, namun mereka kepuasan tersebut memerlukan suatu tambahan biaya peralihan (switching cost) sehubungan dengan upayanya untuk melakukan pergantian ke merek lain.

d. Tingkat keempat adalah konsumen benar-benar menyukai merek tersebut. Pilihan mereka terhadap suatu merek dilandasi pada suatu asosiasi, seperti simbol, rangkaian pengalaman dalam menggunakan merek tersebut maupun kesan kualitas yang tinggi.

e. Tingkat teratas adalah para pelanggan atau konsumen yang setia. Konsumen tipe ini memiliki kebanggaan dalam menemukan atau menjadi pengguna suatu merek.

\section{c. Periklanan}

Periklanan (advertising) adalah segala biaya yang harus dikeluarkan sponsor untuk melakukan presentasi dan promosi non pribadi dalam bentuk gagasan, barang, atau jasa atau dapat pula diartikan sebagai bentuk komunikasi tidak langsung yang didasari pada informasi tentang keunggulan dan keuntungan suatu produk, yang disusun sedemikian rupa sehingga menimbulkan rasa menyenangkan yang akan mengubah pikiran seseorang untuk melakukan pembelian.

\section{d. Tujuan Periklanan}

Tujuan periklanan dapat digolongkan menurut keperluan utamanya yaitu memberi informasi, membujuk atau mengingatkan. Menurut Terence A. Shimp (2003, hlm. 357361) periklanan dihargai karena dikenal sebagai pelaksana beragam fungsi komunikasi yang penting bagi perusahaan, bisnis, dan organisasi lainnya, yaitu Informing, Persuading, Remainding, Adding value dan Assisting. Sedangkan tujuan periklanan berdasarkan sasarannya menurut Kotler (1997, hal. 236) adalah pertama, Periklanan Informatif, yaitu periklanan yang bertujuan untuk membentuk permintaan pertama dengan cara menginformasikan manfaat produk. Kedua, Periklanan Persuasif, yaitu periklanan yang dilakukan dalam tahap kompetitif, tujuannya untuk membentuk permintaan selektif untuk suatu merek tertentu. Ketiga, Periklanan Pengingat, yaitu dilakukan pada produk posisi yang sudah mapan, dengan tujuan meyakinkan pembeli bahwa mereka telah memilih pada pilihan produk yang benar.

\section{e. Media Periklanan Televisi}

Menurut penelitian Nielsen National Media Index 2005 dari AGB Nielsen Media Research, bahwa televisi paling mendominasi dalam konsumsi media nasional televisi mendapat $82 \%$ dalam meraih perhatian dimasyarakat. Televisi mampu menyedot $69 \%$ belanja iklan nasional. Disusul surat kabar sebanyak $26 \%$ dan lantas majalah $5 \%$. Setiap media memiliki kekuarangan dan kelemahan, begitu pula dengan televisi. Faktor-faktor kekuatan iklan di televisi (dan radio) yang dapat mempengaruhi respon konsumen antara lain adalah daya tarik iklan, lama penayangan iklan, frekuensi penayangan iklan serta media penayangan iklan (Simamora, 2003, hal. 206).

Daya tarik iklan membawa dampak pada respon konsumen karena iklan yang menarik tentu lebih mudah mendapatkan perhatian konsumen. Daya tarik iklan terdiri atas daya tarik rasional (menunjukkan bahwa produk memberikan manfaat tertentu), 
emosional (berusaha mengendalikan emosi negatif atau positif yang dapat memotivasi pembelian) dan moral (merujuk pada perasaan mengenai apa yang "benar" atau "pada tempatnya") (Setyawan, 2004, hal. 14). Sedangkan kelemahan Televisi yaitu biaya yang dikeluarkan cukup besar, khalayak yang tidak selektif dan terdapat kesulitan teknis. Menurut Roper Research bahwa jika tingkat saluran menurun, peralatan televisi lengkap dan berfungsi, dan lebih banyak orang yang berpindah saluran ketika iklan berlangsung, tantangan yang dihadapi ialah bagaimana menciptakan iklan yang ingin dilihat orang atau mengikuti pemirsa kemana pun mereka pergi (ke media lain). Oleh karena itu perlu untuk menyusun strategi perancangan iklan yang efektif dan efisien agar pesan iklan dapat diterima dengan baik.

\section{f. Perancangan Iklan Televisi}

1. Strategi merancang iklan televisi. Menurut M. Suyanto (2005) langkah-langkah dalam merancang strategi iklan televisi yaitu pertama, Penetapan audien sasaran, pembidikan pasar dan penetuan posisi. Kedua, Mencari keunggulan produk. Ketiga, menentukan tujuan iklan televisi.

2. Merancang pesan iklan. Strategi perancangan pesan iklan membutuhkan strategi kreatif dengan melewati tahap pembentukan, evaluasi, seleksi dan pelaksanaan pesan. Pembentukan pesan terhadap produk pada prinsipnya merupakan manfaat utama yang ditawarkan merek sebagai konsep produk.

3. Daya tarik iklan televisi. Menetunkan daya Tarik iklan yang tepat sesuai dengan tujuan iklan. Menurut M. Suyanto (2005, hal. 91-111) terdapat beberapa daya tarik pesan dalam iklan televisi diantaranya : Daya tarik pesan, selebriti, humor, rasa takut, kesalahan, musik, komparatif, positif rasional, emosional, seks dan kombinasi.

4. Mengeksekusi gaya pesan iklan. Pesan yang ditampilkan perlu dilihat dari berbagai segi dan yang terpenting dalam mengeksekusi pesan tersebut harus memperhatikan gaya, slogan, logo, simbol, dan format.

5. Kuncinya keterlibatan. Berbagai macam cara dilakukan oleh pemasar untuk membuat orang-orang menonton iklan. Menurut Kenneth, Jane dan Martin (2005, hal. 104) cara yang terbaik agar pemirsa televisi menonton adalah dengan melibatkan pemirsa sehingga mereka ingin menonton televisi dengan janji yang berharga dalam ide kreatif yang kuat. Keterlibatan penonton dalam menikmati iklan dapat mempengaruhi lamanya ingatan audiens akan produk sekaligus mampu mengenali karateristik produk juga dapat mengenali atribut produk dengan baik.

\section{g. Atribut Iklan}

Setiap merek memiliki atribut. Atribut ini perlu dikelola dan diciptakan agar pelanggan dapat mengetahui dengan pasti atribut-atribut apa saja yang terkandung dalam suatu merek. Selain atribut, merek juga memiliki serangkaian manfaat. Konsumen tidak membeli atribut, mereka membeli manfaat. Produsen harus dapat menerjemahkan atribut menjadi manfaat fungsional, maupun emosional (Rangkuti, 2002: 3). Alat komunikasi untuk menterjemahkan atribut merek salah satunya melalui iklan televisi. Sama halnya seperti merek iklanpun memiliki atribut yang perlu untuk dikelola secara baik sehingga mampu memberikan gambaran jelas dalam benak konsumen. Hal ini dikarenakan konsumen kurang mengingat kategori kelas produk saat sebelum melakukan pembelian. Akan tetapi lebih dulu menggunakan memori otak yang berkaitan dengan produk dalam ingatan mereka yang dijadikan acuan sebagai referensi dalam memilih sebuah produk. 
Iklan bekerja melalui sebuah tangapan atau reaksi dari pembeli potensial terhadap atribut yang terkandung dalam iklan. Tanggapan atau reaksi ini dapat terjadi ketika pembeli potensial sedang melihat, mendengar, atau berpikir tentang suatu Iklan. Hal ini didukung oleh pendapat Rossiter dan Percy dalam Olivia Susanti (2007), yang menyatakan bahwa proses untuk menanggapi iklan terbentuk karena adanya rangsangan atribut yang ada dalam iklan. kekuataan iklan terletak pula pada narrative (narasi) atau kisah cerita, atribut iklan yang bersifat intangible. Narasi atau kisah cerita berurusan dengan 'penataan tandatanda, bukan dalam alur logis, melainkan pada susunan kronologisnya' (Tolson, 1996, dalam Jurnal Komunikasi UII oleh Anang hermawan). Bila kita mengamati iklan televisi terdapat beberapa atribut iklan yang memiliki fungsi dan manfaat tersendiri yaitu kisah cerita atau narasi, kata-kata yang terlihat atau tagline, animasi, musik endoser dan warna.

\section{h. Kisah Cerita}

Kisah cerita berurusan dengan 'penataan tanda-tanda, bukan dalam alur logis, melainkan pada susunan kronologisnya' (Tolson, 1996, dalam Jurnal Komunikasi UII oleh Anang hermawan). Hal ini mengungkapkan, kisah cerita hanya sekadar 'rangkaian peristiwa' untuk mengembangkan klimaks cerita. Pada tingkat ini terdapat semacam kerja seni untuk menghasilkan ketertarikan pembaca atas rangkaian kronologis yang disusun oleh pencerita atau kreator iklan sebagaimana yang diutarakan oleh Anang Hermawan dalam Jurnal Komunikasi UII (2007). Dalam iklan, unsur penceritaan dapat ditilik melalui ekspresi serta peranan subyek dalam cerita. Salah satu cara penyajian iklan ditampilkan dalam bentuk kisah cerita yang menggambarkan tujuan utama iklan dan menjelaskan apa yang dilihat (video) dan didengar (audio) pemirsa (Kenneth, Jane dan Martin, 2000, hal. 105). Dalam membuat sebuah iklan, pembuat iklan menyesuaikan pesan yang akan disampaikan dengan karateristik audien. Pendeskripsian kisah cerita dalam iklan tidak perlu terlalu detail tapi dapat dipahami dengan mudah.

\section{i. Tagline}

Menurut Iin Fahima (SWA, 2006) menyatakan bahwa Tagline adalah rangkaian kalimat pendek yang dipakai untuk mengasosiasikan sebuah brand atau perusahaan di benak konsumen. Proses pembuatan tagline sendiri tidak boleh sembarangan. Sebuah tagline harus dibuat dengan memahami product insight dan consumer insight. Setelah proses tersebut dilewati, munculah 'product positioning'. Product positioning biasanya muncul dalam bahasa marketing, belum dalam bahasa komunikasi. Kemudian bahasa marketing tersebut diterjemahkan dalam bahasa konsumen yang hasilnya disebut tagline. Slogan atau tagline yang tertuang dalam pesan iklan merupakan awal dari kesuksesan periklanan. Slogan menjadi pernyataan standar yang mudah diterima di benak konsumen. Slogan mempunyai mempunyai dua fungsi utama yaitu untuk menjaga keberlangsungan serangkaian iklan dalam kampanye dan untuk mensederhanakan sebuah strategi pesan iklan pada pernyataan positioning agar menjadi ringan, dapat diulang, menarik perhatian dan mudah diingat. Tagline atau slogan yang digunakan biasanya merupakan rangkuman yang berbagai pesan yang hendak disampaikan dan merupakan bentuk dari citra terhadap merek.

\section{J. Animasi}

Animasi adalah suatu rangkaian gambar diam secara inbeethwin dengan jumlah yang banyak, bila kita proyeksikan akan terlihat seolah-olah hidup (bergerak) seperti yang pernah kita lihat film-film kartun di televisi maupun dilayar lebar jadi animasi kita simpulkan menghidupkan benda diam diproyeksikan menjadi bergerak 
(www.cepoys.blogspot.com, 2007). Animasi merupakan penggunaan karakter kartun, boneka, atau demonstrasi karakter yang bukan animasi ke dalam kehidupan pada iklan televisi. Teknik animasi tradisional terdiri dari animasi teks, animasi kartun, animasi gambar diam, animasi gambar bergerak dan animasi video. Saat ini, animasi menjadi gaya eksekusi pesan iklan yang sangat populer. Kecanggihan teknologi mampu melahirkan perpaduan antara animasi dan sinematografi dalam industri periklanan di indonesia dan tidak sedikit karakter-karakter yang muncul menjadi ikon pembentuk citra iklan serta animasi membantu memberi solusi terhadap persoalan keterbatasan konsep periklanan (Cakram, 2005, hal. 35). Perpaduan iklan yang memadukan karakter riil dan karakter animasi mampu memberikan kekuataan, seolah-olah karakter animasi memberi wujud nyata yang bisa digunakan untuk mempromosikan iklan.

\section{k. Musik}

Musik adalah penggugah emosi yang kuat. Musik bisa menceritakan apa yang dirasakan dan menggugah perasaan baik perasaan gembira, damai cinta dan ketakutan. (Kenneth, Jane dan Martin, 2000, hal. 117). Musik bisa ditulis khusus atau mengikuti yang telah ada. Kehadirannya musik menjadi salah satu faktor penentu seberapa kuat iklan itu mampu melakukan penetrasi kepada konsumennya (penetration of purchase) (Cakram, 2005, hal. 28). Musik adalah produk pikiran. Menurut Parker (1990, dalam Djohan, 2005, hal. 24) elemen vibrasi (fisika dan kosmos) atau frekuensi, bentuk, amplitudo dan durasi belum menjadi musik bagi manusia sampai semua itu ditransformasikan secara neurologis dan diinterpretasikan melalui otak menjadi pitch, warna suara, keras lembut, dan waktu. Transformasi ke dalam musik dan respon manusia (perilaku) adalah unik untuk dirasa (afeksi) karena otak manusia (kognisi) berkembang dengan amat pesat sebagai akibat pengalaman musikal sebelumnya. Sentuhan musik dan lagu dalam iklan menjadi salah satu faktor penting mendekatkan emosi audien dengan iklan. Keberadaan sebuah iklan, tak hanya ditentukan oleh visualisasi yang elegan perlu dukungan audio yang sesuai dan mampu mendukung tampilan visualisasi. Sentuhan musik yang dipakai mesti menyesuaikan dengan warna musik serta karakter iklan dengan audiens yang ingin dituju.

\section{Endoser}

Seorang model iklan atau bintang iklan merupakan faktor penunjang bagi keberhasilan iklan tersebut dalam menarik minat beli konsumen terhadap produk yang diiklankan. Bintang iklan bisa berupa orang, benda ataupun tokoh kartun. Berbagai media banyak iklan yang menggunakan model, artis, aktor sebagai pendukung produknya. Secara mendalam Lafferty, Barbara A, Ronald E. Goldsmith, and Stephen J. Newell (2000) menunjukkan bahwa endoser yang baik memiliki pengaruh positif pada sikap konsumen terhadap iklan dan sikap konsumen terhadap merek. Namun bukan berarti bahwa endoser yang baik adalah selebriti. Ada beberapa iklan pula yang tidak menggunakan public figur sebagai endosernya. Hal tersebut dimaksudkan agar menambahkan kesan alami tidak dibuat berlebih-lebihan. Sebagai juru bicara produk produk perusahaan, kredibilitas endoser selalu dikaitkan dengan perusahaan. Pada umumnya, jika konsumen mengetahui perusahaan pembuat produk yang diiklankan maka dalam diri konsumen akan muncul beberapa persepsi tentang kredibilitas perusahaan tersebut (Lafferty, Goldsmith, dan Newell 2000). 


\section{m. Warna}

Asosiasi warna memungkinkan identifikasi serta menyampaikan suatu citra dan emosi tertentu. Pengalaman emosional terhadap suatu merek sangat terpengaruh oleh efek warna. Dengan memperhatikan efek warna maka kebutuhan suatu merek tidak hanya terbatas dari sekedar keindahan, kontinuitas dan kecerahan sebagai komponen dari pengalaman merek. Dalam meraih pengalaman emotional ini warna dibanding elemen lainnya adalah sarana yang paling penting. Menurut Marc Gobe (2005, hal. 83), strategy branding melalui warna bukanlah membicarakan merek yang cantik atau indah. Warna adalah tentang menyampaikan informasi penting kepada konsumen anda. Dalam beberapa penelitian ditemukan bahwa terdapat hubungan antara warna dengan kondisi psikologi manusia. Bila diperhatikan pemilihan terhadap warna berbeda-beda tiap orang, hal tersebut menunjukan terdapat pengaruh emosi dalam memilih warna (Darmaprawira, 2002, hal. 31). Warna memicu respon yang sangat spesifik dalam sistem saraf pusat dan korteks otak (cerebral corteks). Sekali mempengaruhi cerebral korteks warna dapat mengaktifkan pikiran, memori dan persepsi tertentu. Stimulan ini mendorong peningkatan kemampuan konsumen untuk merespon informasi. Warna yang dipilih secara tepat mengidentifikasikan logo, produk, tampilan merek anda serta merangsang ingatan yang lebih baik terhadap merek seiring dengan pemahaman yang semakin akurat terhadap keterwakilan merek. Pemillihan warna yang kurang tepat akan mengaburkan pesan, membingungkan konsumen dan dalam mengalami situasi ekstrem, dapat menyebabkan kegagalan suatu merek. Secara tidak langsung warna akan membawa pada identifikasi dan citra produk sehingga mengembangkan asosiasi yang menyebabkan pengaruhnya bertambah kuat.

\section{Korelasi antar atribut iklan sebagai satu kesatuan}

Iklan televisi adalah kombinasi dari komunikasi audio visual yang mempengaruhi kondisi psikologis konsumen melalui tingkatan kognisi, afeksi dan konatif. Perancangan dan pembuataan iklan merujuk pada konsep mengenai produk yang hendak ditampilkan pada iklan televisi. Atribut-atribut iklan perlu penyesuaian antara satu elemen dengan elemen lain pembentuk iklan. Kisah cerita yang merupakan kisah cerita iklan harus mudah dipahami. Pemahaman itu akan lebih jelas dengan slogan atau tagline yang mencerminkan ciri atau identitas produk. Disamping itu penggunaan endoser, animasi, musik serta kombinasi warna merupakan atribut pelengkap lain yang memberikan daya tarik tersendiri dalam sebuah iklan.

\section{c. Model Empiris}

\begin{tabular}{|c|c|}
\hline Atribut Iklan televisi & \\
\hline ○ Alur Cerita & Ekuitas Merek : \\
\hline$\circ \quad$ Tagline & - Kesadaran merek (Brand awareness) \\
\hline$\circ \quad$ Animasi & - Asosiasi merek (brand Asosiasi) \\
\hline ○ Musik & - Kesan Kualitas (Perceived Quality) \\
\hline$\circ \quad$ Endoser & - Loyalitas Merek (Brand Loyalty) \\
\hline O Warna & \\
\hline
\end{tabular}

\section{d. Formula Hipotesis}

1. Diduga atribut iklan seperti kisah cerita atau kisah cerita, kata-kata, animasi, musik, dan warna memiliki pengaruh positif terhadap ekuitas merek.

2. Diduga terdapat atribut iklan yang memiliki pengaruh paling positif terhadap ekuitas merek. 


\section{METODE PENELITIAN}

\subsection{Lokasi Sampel}

Lokasi penelitian berada didaerah Sleman. Sleman merupakan salah satu kota yang memilki penduduk terbesar dan merupakan pusat pendidikan di Yogyakarta sehingga banyak kalangan mahasiswa dari berbagai golongan yang tinggal di kabupaten ini. Kabupaten Sleman dipilih sebagai wilayah pengambilan sampel karena merupakan wilayah dari propinsi D.I. Yogyakarta yang terbanyak terdapat Perguruan Tinggi yaitu 35 perguruan tinggi dari 116 perguruan tinggi yang tersebar di seluruh wilayah propinsi D.I. Yogyakarta (Kopertis Wilayah V D.I. Yogyakarta, Yogyakarta dalam Angka 2005: 18). Dengan demikian diharapkan banyak jumlah perguruan tinggi maka dapat mewakili presentase mahasiswa.

\subsection{Variabel Penelitian}

Terdapat dua variabel dalam penelitian ini yaitu variabel dependen dan variabel independen. Variabel dependen pada penelitian ini adalah atribut iklan dengan dimensidimensi meliputi kisah cerita, tagline, animasi, musik, endoser dan warna. Sedangkan variabel independen dalam penelitian ini adalah ekuitas merek dengan dimensi-dimensi yang meliputi kesadaran merek (brand awareness), asosiasi merek (brand asosiation), kesan kualitas (perceived quality) dan loyalitas merek (brand loyalty).

\subsection{Definisi Variabel Penelitian}

Dalam melakukan penelitian ini, peneliti menggunakan beberapa variabel bebas dan variabel terikat, yaitu

1. Variabel Bebas

Variabel bebas dalam penelitian ini adalah

a. Kisah Cerita $\left(\mathrm{X}_{1}\right)$. Kisah cerita yang dibangun pada iklan akan menceritakan secara tidak langsung mengenai isi pesan yang ingin disampaikan. Disamping itu kisah cerita juga dibuat agar menyenangkan konsumen dalam menikmati iklan.

b. Tagline $\left(\mathrm{X}_{2}\right)$. Pengaruh tagline dalam iklan sangat kuat. Tagline menjelaskan secara tersurat pesan iklan. Pemilihan kata dalam tagline atau slogan memberikan identitas kepada iklan.

c. Animasi $\left(\mathrm{X}_{3}\right)$. Salah satu bentuk multimedia yang digunakan dalam iklan. Animasi yang digunakan lebih pada perpaduan antara sinematografi dan animasi. Animasi digunakan untuk menambah keluwesan penyampaian iklan.

d. Musik ( $\left.\mathrm{X}_{4}\right)$. Latarbelakang musik (jingle) yang seringkali mengiringi iklan. Musik bisa berasal dari kutipan lagu, arranssment khusus untuk produk dan arranssment tetap kutipan lagu yang diubah.

e. Endoser $\left(\mathrm{X}_{5}\right)$. Endoser adalah peran atau model yang memerankan iklan. Endoser bisa berasal dari model, artis, aktor, atau orang biasa. Endoser juga merupakan juru bicara produk sehingga tidak jarang kredibilitas endoser juga berpengaruh terhadap kredibilitas merek.

f. Warna $\left(\mathrm{X}_{6}\right)$. Warna merupakan salah satu komponen penghias grafis. Warna diamini sebagai identitas produk dan mencerminkan sisi kepribadian manusia. Kombinasi warna serta dominasi warna akan berpengaruh terhadap identitas produk dan respon konsumen. 
2. Variabel Terikat/Dependen

Variabel terikat atau dependen (Y) adalah tipe variabel yang dijelaskan atau dipengaruhi oleh variabel independen (Wibisono, 2002, hal. 108). Variabel terikat dalam penelitian ini adalah:

a. Kesadaran Merek (Brand Awareness) ( $\left.\mathrm{Y}_{1}\right)$. Kesadaran merek adalah kesanggupan seseorang calon pembeli untuk mengenali atau mengingat kembali bahwa suatu merek merupakan bagian dari kategori tertentu

b. Asosiasi merek (Brand Asosiation) $\left(\mathrm{Y}_{2}\right)$. Asosiasi merek adalah segala hal yang berkaitan dengan ingatan mengenai merek. Asosiasi itu tidak hanya ada/eksis, namun juga memiliki tingkat kekuatan. Keterkaitan pada suatu merek akan lebih kuat apabila dilandasi pada banyak pengalaman atau penampakan untuk mengkomunikasikannya.

c. Kesan Kualitas (Perceived Quality) ( $\left.\mathrm{Y}_{3}\right)$. Kesan kualitas bisa didefinisikan sebagai persepsi pelanggan terhadap keseluruhan kualitas atau keunggulan suatu produk atau jasa layanan berkaitan dengan maksud yang diharapkan.

d. Loyalitas Merek (Brand Loyalty) $\left(\mathrm{Y}_{4}\right)$. Kepuasan adalah pengukuran secara langsung bagaimana konsumen tetap loyal pada suatu merek. Konsumen akan menjadi setia kepada sebuah produk manakala produk itu memberikan kepuasaan yang dapat dirasakan oleh konsumen. Loyalitas merek adalah ukuran dari kesetiaan konsumen terhadap suatu merek yang dapat dilihat dari tingkatan loyalitas konsumen.

\subsection{Instrumen atau Alat Pengumpul Data}

\subsubsection{Alat Pengumpulan Data}

Kuisioner merupakan teknik pengumpulan data yang dikumpulkan dengan cara memberi seperangkat pertanyaan atau pernyataan tertulis kepada responden untuk dijawabnya (Sugiyono, 2004, hal. 57). Dalam penelitian ini, kuisioner yang dilakukan secara langsung (kontak langsung) antara peneliti dengan responden.

\subsubsection{Skala Pengukuran Variabel}

Pembobotan pada item-item kuesioner menggunakan teknik skoring. Teknik skoring yang digunakan dalam penelitian ini adalah metode skala Likert. Yaitu "Sangat Setuju" diberi nilai 5, "Setuju" diberi nilai 4, "Netral" diberi nilai 3, "Tidak Setuju" diberi nilai 2 dan "Sangat Tidak Setuju" diberi nilai 1.

\subsubsection{Uji Validitas dan Reabilitas Sebaran}

4.4.3.1 Uji Validitas. Validitas yaitu sejauh mana ketepatan dan kecermatan suatu alat ukur dalam melakukan fungsi ukurnya (Azwar, 1992, hal. 35). Validitas digunakan untuk mengetahui kesamaan antar data yang terkumpul dengan data yang sesungguhnya terjadi pada proyek yang diteliti, sehingga dapat diperoleh data yang valid. Instrumen dikatakan valid bila mampu mengukur apa yang seharusnya diukur dan mampu menangkap data yang diteliti dengan tepat. Syarat suatu butir pertanyaan dapat dikatakan valid jika koefisien korelasi product moment lebih dari 0,3 (Azwar, 1992 dalam Suliyanto, 2005, hal. 42) atau nilai Sig. $\leq \alpha$.

4.4.3.2 Uji Reliabilitas. Apabila suatu instrumen telah dinyatakan valid, maka tahap selanjutnya adalah mengukur reliabilitas instrumen. Reliabilitas adalah ukuran yang menunjukkan konsistensi suatu instrumen dalam mengukur gejala yang sama di lain kesempatan. Dalam penelitian ini, pengukuran dilakukan dengan menggunakan teknik korelasi alpha cronbach dimana suatu kuisioner sebagai 
instrumen dikatakan reliabel jika nilai alpha cronbach lebih besar dari 0,60 (Santosa, 2005, hal. 251).

\subsection{Populasi dan Sampel}

\subsubsection{Teknik Pengambilan Sampel}

Pada penelitian ini menggunakan non probability sampling, yaitu elemen-elemen populasi tidak mempunyai kesempatan yang sama untuk terpilih menjadi sampel (Nur Indriantoro dan Bambang Supomo, 1999, hal. 130). Dalam penarikan sampel, peneliti menggunakan metode purposive sampling yaitu pemilihan sampel secara acak yang informasi diperoleh dengan menggunakan pertimbangan tertentu (umumnya disesuaikan dengan tujuan atau masalah penelitian) yaitu sebagian besar mahasiswa aktif di Yogyakarta yang pernah menyaksikan iklan Sprite versi Speed.

\subsubsection{Penentuan Jumlah Sampel}

Ukuran sampel memegang peranan penting dalam estimasi dan interpretasi hasilhasil SEM. Berdasarkan atas pendapat Hair, et al dalam Augusty Rerdinad (2002, hal. 47) menyatakan bahwa ukuran sampel yang sesuai analisis SEM adalah antara 100-200 sampel. Umar (2002, hal. 149) menyatakan bahwa karena jumlah anggota populasi begitu banyak dan tidak diketahui jumlahnya secara pasti, maka besarnya sampel ditetapkan dengan rumus sebagai berikut:

$$
\mathrm{n}=\frac{(\mathrm{Z} 1 / 2 \alpha \times \sigma)^{2}}{\mathrm{E}^{2}}
$$

Keterangan:

$\mathrm{n}=$ Jumlah sampel

$\mathrm{Z}=$ Nilai yang diperoleh dari tabel $\mathrm{Z}$ pada level of confidence tertentu

$\sigma=$ Standard deviasi dari populasi. Karena standard deviasi tidak diketahui, digunakan perkiraan sesuai dengan pengalaman sebelumnya jika ada. Jika tidak ada pengalaman sebelumnya, yang dapat dilakukan adalah perkiraan saja.

$\mathrm{E}=$ Error of estimate. Kesalahan yang dapat ditoleransi dalam level of confidence tertentu $(\chi-\mu)$

Dengan taraf signifikasi $(\alpha)=5 \%, Z 1 / 2 \alpha=1,96$ (Tabel distribusi $Z$ dengan $\alpha=5 \%$ ). Standard kesalahan maksimum dan standard deviasi yang ditetapkan yaitu $10 \%$ dan 0,5 . Dengan demikian, setelah dimasukkan dalam rumus menjadi $\mathrm{n}=(1,96 \times 0,5)^{2} /(0,1)^{2}=96,4$ dibulatkan menjadi 100 . agar lebih menjamin keyakinan dan memudahkan penelitian maka sampel minimal dibulatkan keatas jadi 100. Hal ini pula dilakukan agar memenuhi kriteria kecukupan data seperti yang disyaratkan untuk penggunaan SEM. Oleh karena itu penelitian ini akan diambil sampel sebanyak 100 responden di Kabupaten Sleman yang pernah menyaksikan iklan Sprite versi Speed di televisi.

\section{HASIL DAN PEMBAHASAN}

Dari hasil penelitian diketahui responden terbanyak adalah mahasiswa yang berumur 20 tahun yaitu sebanyak 38\%, sedangkan responden paling sedikit adalah mahasiswa yang berumur 26 tahun yaitu sebanyak 3\%. Responden terbanyak adalah responden dengan jenis kelamin laki-laki yaitu sebanyak $61 \%$, sedangkan responden 
perempuan sebanyak 39\%. Responden yang paling banyak adalah mahasiswa yang berasal dari Universitas Islam Indonesia yaitu sebanyak 58\%, sedangkan responden yang paling sedikit adalah mahasiswa yang berasal dari AMPTA yaitu sebanyak 9\%. Responden terbanyak adalah mahasiswa yang pada saat ini sedang menempuh pendidikan sarjana S1 yaitu sebanyak 21\%, sedangkan responden yang saat ini menempuh pendidikan diploma 3 (D3) sebanyak 21\%, dan responden yang saat ini menempuh pendidikan sarjana S2 sebanyak 11\%.

\subsection{Deskripsi Data}

Statistik deskriptif digunakan untuk memberikan deskripsi mengenai data penelitian. Variabel yang diteliti dalam penelitian ini adalah atribut iklan televisi dan ekuitas merek. Statistik deskriptif masing-masing variabel penelitian menunjukkan bahwa rata-rata tanggapan responden terhadap variabel kisah cerita adalah 3,863 dengan standar deviasi 0,641. Rata-rata tanggapan responden terhadap variabel tagline adalah 3,782 dengan standar deviasi 0,739. Rata-rata tanggapan responden terhadap variabel animasi adalah 3,643 dengan standar deviasi 0,74. Rata-rata tanggapan responden terhadap variabel musik adalah 3,567 dengan standar deviasi 0,859. Rata-rata tanggapan responden terhadap variabel endoser adalah 3,35 dengan standar deviasi 0,769. Rata-rata tanggapan responden terhadap variabel warna adalah 3,372 dengan standar deviasi 0,717. Rata-rata tanggapan responden terhadap variabel ekuitas merek adalah 3,416 dengan standar deviasi 0,638. Hasil analisis deskriptif tersebut menunjukkan bahwa tanggapan responden terhadap variabel penelitian termasuk kategori cukup baik $(>3,00)$. Hal ini berarti bahwa atribut iklan televisi dan ekuitas merek yang dinilai oleh responden relatif adalah cukup baik.

\subsection{Analisa Data}

Pengujian asumsi yang seharusnya terpenuhi oleh SEM dengan menggunakan program LISREL adalah uji normalitas data dan uji multicolinearity (Ghozali dan Fuad, 2005, hal. 36).

\subsubsection{Uji Normalitas Data}

Nilai statistik untuk menguji normalitas dilihat dari ukuran skewness dan kurtosis sebaran data. Bila nilai $p$-value lebih besar dari $\alpha=0,05$ maka dapat dinyatakan bahwa distribusi data normal. Hasil uji normalitas data disajikan pada tabel berikut ini:

Tabel 4.9

Hasil Uji Normalitas Data

\begin{tabular}{|l|r|r|r|r|}
\hline \multirow{2}{*}{ Variabel } & \multicolumn{2}{|c|}{ Skewness } & \multicolumn{2}{c|}{ Kurtosis } \\
\cline { 2 - 5 } & z-score & \multicolumn{1}{c|}{ P } & z-score & \multicolumn{1}{c|}{ P } \\
\hline Cerita & $-0,227$ & 0,820 & $-0,27$ & 0,787 \\
\hline Tagline & $-0,153$ & 0,879 & $-0,274$ & 0,784 \\
\hline Animasi & $-0,250$ & 0,803 & 0,004 & 0,997 \\
\hline Musik & $-0,128$ & 0,898 & $-0,232$ & 0,816 \\
\hline Endoser & 0,049 & 0,961 & $-0,041$ & 0,967 \\
\hline Warna & $-0,026$ & 0,979 & 0,112 & 0,911 \\
\hline Ekuitas Merek & $-0,001$ & 0,999 & 0,122 & 0,903 \\
\hline
\end{tabular}

Sumber: Data diolah, 2003 
Berdasarkan hasil uji normalitas diketahui bahwa semua variabel penelitian berada mempunyai nilai $p$-value lebih besar dari $\alpha=0,05(\mathrm{P}>0.05)$. Dengan demikian hasil pengujian ini menunjukkan bahwa semua data penelitian berdistribusi normal.

\subsubsection{Uji Multicolinearity}

Salah satu asumsi yang harus dipenuhi adalah multicollinearity. Asumsi multikolinearitas menyatakan bahwa variabel independen harus terbebas dari adanya korelasi antar variabel independen. Asumsi ini mengharuskan tidak adanya korelasi yang sempurna atau besar diantara variabel-variabel independen. Nilai korelasi antara variabel observed yang tidak diperbolehkan adalah sebesar 0,9 atau lebih. Hasil uji multicollinearity dapat dilihat pada tabel berikut.

Tabel 4.10

Hasil Uji Multicollinearity

\begin{tabular}{|l|c|c|c|c|c|c|}
\hline & Cerita & Tagline & Animasi & Musik & Endoser & Warna \\
\hline Cerita & - & 0,47 & 0,10 & 0,35 & 0,53 & 0,30 \\
\hline Tagline & 0,47 & - & 0,43 & 0,51 & 0,70 & 0,29 \\
\hline Animasi & 0,10 & 0,43 & - & 0,46 & 0,46 & 0,54 \\
\hline Musik & 0,35 & 0,51 & 0,46 & - & 0,61 & 0,47 \\
\hline Endoser & 0,53 & 0,70 & 0,46 & 0,61 & - & 0,51 \\
\hline Warna & 0,30 & 0,29 & 0,54 & 0,47 & 0,51 & - \\
\hline
\end{tabular}

Sumber: Data diolah, 2003

Berdasarkan hasil uji multicollinearity seperti terlihat pada Tabel 4.9 diketahui bahwa semua korelasi antar variabel independen mempunyai nilai korelasi kurang dari 0,90. Dengan demikian dapat disimpulkan bahwa pada model ini terbebas dari gejala adanya multicolinearity.

\subsection{Uji Goodness of Fit Model}

Model teoritis pada kerangka konseptual penelitian, dikatakan fit jika didukung oleh data empirik. Hasil pengujian goodness of fit overall model digunakan untuk mengetahui apakah model hipotetik didukung oleh data empirik. Hasil komputasi Lisrel untuk model SEM ini dihasilkan indeks-indeks goodness of fit yang menunjukkan kelayakan model seperti disajikan pada tabel berikut.

Tabel 4.11

Goodness of Fit Index

\begin{tabular}{|l|c|c|}
\hline \multicolumn{1}{|c|}{ Goodness of Fit } & Hasil Analisis & Cut-off Value \\
\hline$\chi^{2}$-Chi-Square & 329,49 & Diharapkan kecil \\
\hline Probability & 0,001 & $\geq 0,05$ \\
\hline CMIND/DF & 1,297 & $\leq 2$ \\
\hline GFI & 0,790 & $\geq 0,90$ \\
\hline AGFI & 0,730 & $\geq 0,90$ \\
\hline CFI & 0,930 & $\geq 0,90$ \\
\hline TLI/NNFI & 0,92 & $\geq 0,90$ \\
\hline RMSEA & 0,055 & $\leq 0,08$ \\
\hline
\end{tabular}

Sumber: Data primer diolah 
Hasil Goodness of Fit diperoleh nilai Chi-Square sebesar 329,49 dengan probabilitas 0,001 menunjukkan bahwa nilai tersebut masih diatas nilai yang diharapkan. Nilai CMIN/DF sebesar 1,297 yang berarti lebih kecil dari 2 menunjukkan bahwa model fit. Indeks kriteria fit yang lain yaitu GFI dan AGFI. Secara teortis angka GFI mapun AGFI berkisar antara 0 sampai 1, dengan pedoman bahwa semakin hasil GFI dan AGFI mendekati angka 1 maka akan semakin baik model tersebut dalam menjelaskan data yang ada (Singgih Susanto, 2007, hal. 101) dari kedua data diatas menunjukan bahwa GFI dan AGFI telah mendekati nilai yang direkomendasikan sehingga dapat dinyatakan model cukup fit (sedang). Nilai AGFI dan GFI serta CMIN/DF yang memenuhi syarat keerataan data dan semua menunjukan dukungan terhadap nilai Chi-Square. Disamping itu nilai CFI sebesar 0, 930 menunjukan bahwa model fit. Nilai TLI/NNFI sebesar 0, 92 menunjukan bahwa model fit. Nilai RMSEA sebesar 0,055 yang berarti kurang dari 0,08 menunjukkan bahwa model fit sesuai dengan nilai yang direkomendasikan. Menurut Singgih Santoso (2007, hal. 141) mengatakan bahwa angka korelasi cut off (standar) pada prakteknya tidak ada pedoman yang pasti namun angka diatas 0,7 atau dapat pula diatas 0,5 pada umumnya dijadikan acuan adanya keerataan antar dua variabel. Hasil pengujian goodness of fit secara keseluruhan menunjukkan bahwa model memiliki cut off diatas 0,7 sehingga dapat dikatakan bahwa model tersebut memiliki keerataan dan cukup baik (cukup fit).

\subsection{Uji Hipotesis}

Pengujian hipotesis penelitian dilakukan dengan menganalisis hubungan antar variabel sesuai dengan model penelitian. Untuk menerima hipotesis alternatif bahwa terdapat pengaruh variabel independen terhadap variabel dependen dapat dinilai dari nilai $\mathrm{t}$-value. Hipotesis alternatif diterima apabila $\mathrm{t}$-value $>1,96$. Ringkasan hasil pengujian hipotesis penelitian dapat dilihat sebagai berikut:

Tabel 4.12

Hasil Pengujian Hipotesis

\begin{tabular}{|l|c|c|}
\hline \multicolumn{1}{|c|}{ Variabel } & Estimate & t value \\
\hline Cerita & 0,250 & 2,460 \\
\cline { 3 - 3 } Tagline & 0,310 & 2,490 \\
\hline Animasi & 0,013 & 0,120 \\
\hline Musik & 0,230 & 2,290 \\
\hline Endoser & 0,290 & 2,100 \\
\hline Warna & 0,003 & 0,024 \\
\hline
\end{tabular}

Sumber: Data diolah, 2003

Hasil analisis untuk menguji apakah kisah cerita berpengaruh terhadap ekuitas merek diperoleh estimate sebesar 0,250 dengan t-value $=2,460$. Oleh karena t-value $>$ 1,96 maka hipotesis yang menyatakan bahwa kisah cerita berpengaruh positif terhadap ekuitas merek dapat diterima. Hasil analisis menunjukkan bahwa atibut kisah cerita pada iklan televisi Sprite versi Speed berpengaruh positif terhadap ekuitas merek.

Kisah cerita yang disajikan pada suatu iklan menggambarkan tujuan utama iklan dan menjelaskan apa yang dilihat dan didengar oleh pemirsa televisi. Kisah cerita yang merupakan kisah cerita iklan harus mudah dipahami. Semakin jelas kisah cerita yang ditampilkan pada iklan, maka akan meningkatkan kesadaran merek (brand awareness), asosiasi merek (brand asosiasi), kesan kualitas (perceived quality), dan loyalitas merek (brand loyalty). Sebuah iklan harus menyesuaikan pesan yang akan disampaikan dengan 
karateristik audien. Pendeskripsian kisah cerita dalam iklan tidak perlu terlalu detail tapi dapat dipahami dengan mudah sehingga dapat diterima oleh konsumen yang selanjutnya akan meningkatkan ekuitas merek tersebut.

Hasil analisis untuk menguji apakah tagline berpengaruh terhadap ekuitas merek diperoleh estimate sebesar 0,310 dengan $\mathrm{t}$-value $=2,490$. Oleh karena $\mathrm{t}$-value $>1,96$ maka hipotesis yang menyatakan bahwa tagline berpengaruh positif terhadap ekuitas merek dapat diterima. Hasil analisis menunjukkan bahwa atibut tagline pada iklan televisi Sprite versi Speed berpengaruh positif terhadap ekuitas merek. Tagline adalah rangkaian kalimat pendek yang dipakai untuk mengasosiasikan sebuah brand atau perusahaan di benak konsumen. Semakin baik penerimaan konsumen terhadap slogan atau tagline yang tertuang dalam pesan iklan, maka akan semakin tinggi ekuitas merek yang dapat terbentuk. Slogan menjadi pernyataan standar yang mudah diterima di benak konsumen. Tagline atau slogan yang digunakan merupakan rangkuman dari berbagai pesan yang hendak disampaikan dan merupakan bentuk dari citra terhadap merek. Tagline pada iklan yang menarik perhatian dan mudah diingat akan meningkatkan kesadaran merek (brand awareness), asosiasi merek (brand asosiasi), kesan kualitas (perceived quality), dan loyalitas merek (brand loyalty). Tagline akan semakin efektif jika kata-kata sebagai penyambung bahasa pesan yang ada di dalam iklan televisi mudah dipahami dan katakata tidak asing bagi konsumen.

Hasil analisis untuk menguji apakah animasi berpengaruh terhadap ekuitas merek diperoleh estimate sebesar 0,013 dengan t-value $=0,120$. Oleh karena t-value $<1,96$, maka hipotesis yang menyatakan bahwa animasi berpengaruh positif terhadap ekuitas merek tidak didukung. Animasi merupakan penggunaan karakter kartun, boneka, atau demonstrasi karakter yang bukan animasi ke dalam kehidupan pada iklan televisi. Animasi adalah suatu rangkaian gambar diam secara inbeethwin dengan jumlah yang banyak, bila diproyeksikan akan terlihat seolah-olah hidup (bergerak). Atribut animasi pada iklan televisi Sprite versi Speed tidak berpengaruh signifikan terhadap ekuitas merek. Hal ini dapat disebabkan karena penggunaan animasi pada iklan televisi Sprite versi Speed relatif sedikit sehingga tidak berpengaruh terhadap terbentuknya ekuitas merek produk Sprite. Hasil analisis untuk menguji apakah musik berpengaruh terhadap ekuitas merek diperoleh estimate sebesar 0,230 dengan t-value $=2,290$. Oleh karena tvalue $>1,96$ maka hipotesis yang menyatakan bahwa musik berpengaruh positif terhadap ekuitas merek dapat diterima. Semakin baik penerimaan konsumen terhadap musik yang disertakan pada penyajian iklan televisi, maka semakin tinggi pengaruhnya terhadap pembentukan ekuitas merek.

Musik merupakan penggugah emosi yang kuat yang dapat menceritakan apa yang dirasakan dan menggugah dapat perasaan gembira pada konsumen. Kehadiran musik menjadi salah satu faktor penentu seberapa kuat iklan itu mampu melakukan penetrasi kepada konsumennya. Keberadaan sebuah iklan tidak hanya ditentukan oleh visualisasi yang elegan, tetapi juga perlu dukungan audio yang pas dan mampu mendukung tampilan visualisasi. Sentuhan musik dan lagu dalam iklan menjadi salah satu faktor penting mendekatkan emosi audien dengan iklan. Sentuhan musik yang dipakai mesti menyesuaikan dengan warna musik serta karakter iklan dengan audiens yang ingin dituju. Semakin kuat sentuhan musik dalam mempengaruhi konsumen melalui iklan, maka akan semakin tinggi pengaruhnya terhadap kesadaran merek (brand awareness), asosiasi merek (brand asosiasi), kesan kualitas (perceived quality), dan loyalitas merek (brand loyalty).

Hasil analisis untuk menguji apakah endoser berpengaruh terhadap ekuitas merek diperoleh estimate sebesar 0,290 dengan $t$-value $=2,100$. Oleh karena $t$-value $>1,96$ 
maka hipotesis yang menyatakan bahwa endoser berpengaruh positif terhadap ekuitas merek dapat diterima. Semakin kuat karakter endorser yang akan semakin berpengaruh positif pada sikap konsumen terhadap iklan dan sikap konsumen terhadap merek.

Endoser yang baik bukan hanya berasal dari seorang selebriti. Ada beberapa iklan pula yang tidak menggunakan public figur sebagai endosernya seperti pada iklan Sprite versi Speed. Hal tersebut dimaksudkan agar menambahkan kesan alami tidak dibuat berlebih-lebihan. Sebagai juru bicara produk produk perusahaan, kredibilitas endoser selalu dikaitkan dengan perusahaan. Pada umumnya, jika konsumen mengetahui perusahaan pembuat produk yang diiklankan maka dalam diri konsumen akan muncul beberapa persepsi tentang kredibilitas perusahaan tersebut. Endoser yang baik memiliki pengaruh positif terhadap kesadaran merek (brand awareness), asosiasi merek (brand asosiasi), kesan kualitas (perceived quality), dan loyalitas merek (brand loyalty). Hasil analisis untuk menguji apakah warna berpengaruh terhadap ekuitas merek diperoleh estimate sebesar 0,003 dengan $\mathrm{t}$-value $=0,024$. Oleh karena $\mathrm{t}$-value $<1,96$ maka hipotesis yang menyatakan bahwa warna berpengaruh positif terhadap ekuitas merek tidak didukung. Atribut warna pada iklan televisi Sprite versi Speed tidak berpengaruh signifikan terhadap pembentukan ekuitas merek. Hal ini dapat disebabkan karena pemillihan warna yang kurang tepat, sehingga akan mengaburkan pesan, membingungkan konsumen, dan apabila mengalami situasi yang ekstrem dapat menyebabkan kegagalan suatu merek. Pemberian warna pada iklan ada yang kurang dominan secara tidak langsung mempengaruhi identifikasi dan citra produk sehingga menyebabkan lemahnya pengaruh terhadap ekuitas merek. Secara jelas hasil pengujian analisis data penelitian untuk membuktikan hipotesis yang diajukan dapat dilihat pada gambar berikut:

Gambar 4.1

Hasil Pengujian Model Penelitian

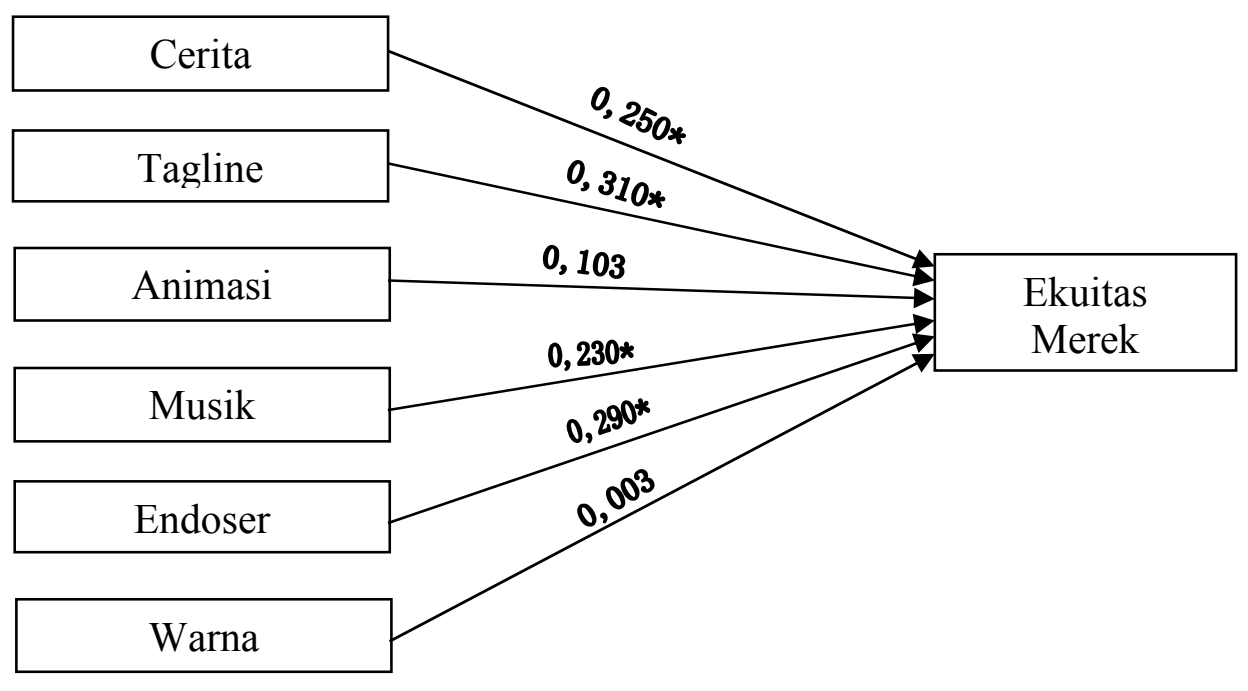

* Estimate Signifikan pada 5\%

Berdasarkan gambar tersebut di atas dapat disimpulkan bahwa atribut iklan televisi pada iklan televisi Sprite versi Speed yang berpengaruh positif terhadap ekuitas merek adalah kisah cerita, tagline, musik, dan endoser. Sedangkan atribut animasi dan warna tidak berpengaruh signifikan terhadap ekuitas merek pada produk Sprite.

Berdasarkan hasil analisis juga dapat diketahui atribut iklan televisi yang paling positif pengaruhnya terhadap ekuitas merek adalah atribut tagline dengan estimate sebesar 0,310 dengan t-value $=2,490$ dimana $\mathrm{t}$-value $>1,96$. Hal ini dapat disebabkan 
karena tagline adalah atribut yang identik dengan merek suatu produk. Tagline adalah atribut iklan yang dipakai untuk mengasosiasikan sebuah brand atau perusahaan dibenak konsumen. Tagline merupakan atribut merek yang mudah dipahami, mudah diingat, dan kata-katanya sering digunakan dalam kehidupan sehari-hari. Berikutnya secara berturutturut yang paling mempengaruhi ekuitas merek pada produk Sprite adalah kisah cerita estimate sebesar 0,250 dengan t-value $=2,460$ dimana $t$-value $>1,96$, musik dengan nilai estimate sebesar 0,230 dengan t-value $=2,290$ dimana $t$-value $>1,96$ dan endoser dengan nilai estimate sebesar 0,290 dengan $\mathrm{t}$-value $=2,100$ dimana $\mathrm{t}$-value $>1,96$. Sedangkan atribut animasi dan warna juga berpengaruh positif tetapi tidak signifikan terhadap pembentukan ekuitas merek pada produk Sprite. Hal ini dapat ditunjukan oleh hasil analisis animasi dengan nilai estimate sebesar 0,013 dengan dengan t-value $=0,120$ dimana t-value $<1,96$ dan warna dengan nilai sebesar 0,003 dengan dengan $\mathrm{t}$-value $=$ 0,024 dimana t-value $<1,96$.

\section{KESIMPULAN}

Berdasarkan analisis data penelitian yang sudah dilakukan, dapat diambil kesimpulan sebagai berikut:

1. Pengujian goodness of fit (GFO) menunjukan chi-square yang besar $(329,49)$ dan probabilitas yang kecil $(0,001)$ sementara hasil chi-square yang diharapkan adalah lebih kecil dan tingkat probabilitas diatas 0,05 atau $p>0,05$. Namun pada pengujian SEM, chi-square bukanlah satu-satu acuan untuk menilai sebuah model fit atau tidak. Untuk itu para peniliti mengembangkan model-model yang dapat memperbaiki bias karena jumlah sampel yang besar dan kompleksitas model diantaranya CMIN/DF, GFI, AGFI, CFI, TLI/NNFI, RMSEA. Model-model tersebut secara keseluruhan dianggap cukup fit dengan masing-masing indikator menunjukan nilai diatas 0,07 untuk nilai $\mathrm{GFI}=0,790, \mathrm{AGFI}=0,730, \mathrm{CFI}=0,930$ dan TLI/NNFI $=0,92$, menandakaan adanya keerataan terhadap data serta nilai CMIN/DF sebesar 1,297 dari cut off $\leq 2$ serta nilai RMSEA sebesar 0, 055 dari cut off $\leq 0,08$ menunjukan bahwa kedua model tersebut fit.

2. Adapun hasil pengujian hipotesis ini menyatakan bahwa atribut iklan televisi pada iklan televisi Sprite versi Speed yang berpengaruh positif terhadap ekuitas merek adalah kisah cerita, tagline, musik, dan endoser hal ini dapat dilihat dari hasil hipotesis dengan menggunakan Structure Equation Modeling (SEM) yang menunjukan nilai t-value lebih besar dari 1, 96 untuk variabel kisah cerita $\left(\mathrm{X}_{1}\right)$ sebesar 2,460, tagline $\left(\mathrm{X}_{2}\right)$ sebesar 2,490, musik $\left(\mathrm{X}_{4}\right)$ sebesar 2,290, dan endoser $\left(\mathrm{X}_{5}\right)$ sebesar 2,100. Sedangkan atribut animasi dan warna tidak berpengaruh signifikan terhadap ekuitas merek pada produk Sprite. Hal ini dikarenakan nilai tvalue lebih kecil dari 1, 96 atau berada diantara -1,96 sampai dengan 1,96 dimana untuk variabel atribut animasi $\left(\mathrm{X}_{3}\right)$ sebesar 0,120 dan warna $\left(\mathrm{X}_{6}\right)$ sebesar 0, 024 . Secara keseluruhan bahwa atribut iklan berpengaruh terhadap ekuitas merek.

3. Atribut iklan televisi yang paling positif pengaruhnya terhadap ekuitas merek adalah tagline dengan tingkat t-value yang lebih tinggi diantara variabel atribut iklan yang lain yaitu sebesar 2, 490. Hal ini diperkuat dengan nilai estimasi yang tertinggi pula sebesar 0,310 . 


\section{DAFTAR PUSTAKA}

Aaker, David A. (terj.) (1997). Manajemen Ekuitas Merek: Memanfaatkan Nilai dari Suatu Merek. Jakarta: Spektrum.

Anomin (2005). “ Jingle Bukan Sekedar Lagu”. Cakram, Agustus, 28.

Anomin (2005). "Padu Padan Karakter Animasi”. Cakram, Oktober, 32.

Arry Yulianto, N. (2006). Analisis Pengaruh Ekuitas Merek Terhadap Keputusan Pembelian Konsumen Pada Handphone Nokia (Studi kasus pada Mahasiswa Fakultas Ekonomi UII Yogyakarta). Skripsi S-1 (tidak dipublikasikan). Yogyakarta: Fakultas Ekonomi UII.

Darmanto Durianto, Sugiarto, Lie Joko Budiman (2004). Brand Equity Ten: Strategi Memimpin Pasar. Jakarta: PT. Gramedia Pustaka Utama.

Darmaprawira, W.A. S. (2002). Warna: Teori dan Kreativitas Penggunaannya. Bandung: Penerbit ITB

Djohan (2005). Psikologi Musik. Yogyakarta: Penerbit Buku Baik Yogyakarta.

Fahima, I. (2006). Perbedaan Tagline, Slogan Iklan dan Kredo. Diambil 30 April 2008 dari http://www.swa.co.id/sekunder/konsultasi/pemasaran/advertising/details.php.

Ferdinand, Agusty (2002). Structural Equation Modeling dalam Penelitian Manajemen. Semarang: Badan Penerbit UNDIP.

Fisk, Peter (terj.) (2005). Marketing Genius. Jakarta: PT. Elex Media Komputindo.

Gail, Tom (2000). Marketing With Music. Jurnal of Consmer Marketing.

Ghozali dan Fuad (2005). Aplikasi Analisis Multivariate dengan Program SPSS, Edisi 3. Semarang: BP-Undip.

Gobe, Marc (2005). Emotional Branding. Jakarta: Erlangga.

Hari Wijayanto S. (2008). Struktural Equation Modeling dengan Lisrel 8.8: Konsep dan Tutorial. Yogyakarta: Graha Ilmu.

Hermawan, Anang (2007). “Membaca” Iklan Televisi: Sebuah Perspektif Semiotika. Artikel Jurnal Komunikasi UII Volume 2 No. 1. Oktober 2007.

Kenneth, Jean Maas, Martin Nesenholts (terj.) (2005). How To Advertise. Jakarta: PT. Elex Media Komputindo.

Khasali, R. (1993). Manajemen Periklanan: Konsep dan Aplikasinya di Indonesia, Edisi ketiga. Jakarta: PAU Ekonomi UI.

Knapp, D. (terj.) (2001). The Brand Mindset. Edisi 1. Cetakan 1. Yogyakarta: Penerbit Andi. 
Kotler, Philip dan Gary Amstrong (terj.) (1995). Dasar-dasar Pemasaran. Jilid 1, Edisi Keenam. Jakarta: CV Intermedia.

Lafferty, Barbara A, and Goldsmith (2002). The Dual Credibility Model: The Influence of Corporate and Endorser Credibility on Attitudes and Purchase Intentions. Journal of Marketing Theory and Practicel.

Rangkuti, Freddy (2002). The Power of Brand. Jakarta: PT. Gramedia Pustaka Utama.

Schiffman, L.G. dan Kanuk, L.L. (terj.) (2004). Perilaku Konsumen. Edisi ketujuh: Prentice Hall International.

Schulz, Eric (terj) (2003). Marketing Game. Jakarta: Erlangga.

Shimp, Terrence. A. (2003). Periklanan, Promosi dan Aspek Tambahan Komunikasi Pemasaran Terpadu. Edisi kelima. Jilid 1. University of South California. Jakarta: Erlangga.

Simamora, Bilson (2002). Aura Merek: 7 Langkah Membangun Merek yang Kuat. Jakarta: PT. Gramedia Pustaka Utama.

Singh, Satyendra (2006). Impact of Color on Marketing. Journal of Management Decision. University of Winnipeg. Canada

Soehadi, A. W. (2005). Efektif Branding: Konsep dan Aplikasi Pengembangan Merek yang Sehat dan Kuat. Bandung: PT. Mizan Pustaka

Susanto, Singgih (2007). Structural Equation Modelling: Konsep dan Aplikasi AMOS. Jakarta: PT Elex Media Komputindo.

Susanti, Olivia (2007). Mengungkapkan Makna Iklan Rexona "Cheerleader Pria” di Televisi. Skripsi S 1. Surabaya. Universitas Kristen Petra.

Susi Evanita, Afnidarti AR dan Armida S. (2007). Pengaruh Terpaan Iklan Televisi Terhadap Perilaku Konsumtif Ibu Rumah Tangga di Kota Padang Sumatera Barat. Skripsi S 1. Padang: Universitas Negeri Padang.

Suyanto M. (2005). Strategi Perencanaan Iklan Televisi Perusahaan Top Dunia. Yogyakarta: Penerbit ANDI.

Suyanto M. (2004). Analisisi dan Desain Aplikasi Multimedia untuk Pemasaran. Yogyakarta: Penerbit ANDI.

Swastha, Basu dan T Hani Handoko (1982). Manajemen Pemasaran Analisa Perilaku Konsumen, Edisi Pertama. Yogyakarta: Liberty.

Tholib, M. (2007). Pengertian Animasi. Diambil 30 April 2008 dari http://mtholib.wordpress.com/2007/08/21/pengertian-animasi/. 
Wibisono, Dermawan (2002). Riset Bisnis Untuk Praktisi dan Akademis. Jakarta: PT. Gramedia Pustaka Utama.

Yeni Maesaroh. S. (2006). Pengaruh Kekuatan Iklan Frestea Green Di Televisi Terhadap Respon Konsumen Di Yogyakarta Berdasarkan Model Hierarki Efek. Tesis S-2. Yogyakarta: Fakultas Ekonomi UII. 